\title{
Endophytic Bacteria: an Essential Requirement of Phyto Nutrition
}

\author{
Shatrupa Ray ${ }^{1,2}$, Jyoti Singh ${ }^{1}$, Rahul Singh Rajput ${ }^{2}$, Harikesh Bahadur Singh ${ }^{2}$, Surendra Singh ${ }^{1 *}$ \\ ${ }^{1}$ Department of Botany, Institute of Science, Banaras Hindu University, India
}

${ }^{2}$ Department of Mycology and Plant Pathology, Institute of Agricultural Sciences, Banaras Hindu University, India

Submission: December 15, 2017; Published: February 09, 2018

*Corresponding author: Surendra Singh, Department of Botany, Institute of Sciences, Banaras Hindu University, Varanasi, India, Tel: +91-9450414985 ,Email: surendrasingh.bhu@gmail.com

\begin{abstract}
An incessant upsurge in the use of chemical fertilizers has led to several disastrous effects on agriculture and environment. Biological control has provided a plausible alternative to lower down the usage of chemical fertilizers. Plant associated microorganisms play an important role in sustainable agriculture for enhancing plant growth, productivity as well as stress amelioration. Endophytic microbes, residing in plant play a powerful role in exerting their beneficial attributes with a higher consistency, particularly since they dwell in a relatively secure environment, largely protected from the externally induced abiotic/biotic stresses. However, irrespective of the multi-faceted benefits of endophytic bacteria, the role of these microbes in agriculture still remains unrealized and unexploited. In this work, we have described the endophyte-plant interactions taking into consideration the several aspects of endophytic activity to enhance awareness towards the application of endophytic bacteria in organic farming.
\end{abstract}

Keywords : Endophytic bacteria; Biofertilizer; Plant nutrition; Oxidative stress; Antioxidants

Abbreviations : Aims: Agriculturally Important Microbes; NAFTA: North American Free Trade Agreement; PGP: Plant Growth Promotion; PGPR: Plant Growth Promoting Rhizobia; IAA: Indole Acetic Acid; ACC: 1-Aminocyclopropane-1-Carboxylate; Alss: Acetolate Synthase; Alsd: Acetolactate Decarboxylase; ISR: Induced Systemic Resistance; SAR: Systemic Acquired Resistance

\section{Chemical Fertilizers: The Archaic Practice of Sustainable Agriculture}

Agricultural advancements, particularly green revolution, enforced the use of chemical pesticides for greater production and higher yield. However, persistent chemo inputs into soil over the years have rendered a catastrophic effect on the soil micro-biota as well as on human health [1-3]. This is quite evident from the fact that many Indian states have been rendered completely unproductive while there is a significant upsurge of certain deadly diseases, such as cancer, diabetes, hypertension etc. due to a constant exposure to the chemical compounds. Degradation rates of the chemical fertilizers are quite negligible owing to their complex structures. This leads to their bioaccumulation and bio-magnification thereby resulting in a loss in specific biodiversity apart from severe groundwater contamination. Apart from the aforementioned concerns, an exponentially increasing human population along with a persistent caveat of abiotic stress, particularly with respect to Indian perspective, is demanding the utilization of other eco friendly alternatives chiefly to ensure food security.

This paves the way for plausible cost efficient, eco-friendly and sustainable alternatives for yield improvement, such as use of agriculturally important microbes (AIMs) which have for long attracted the attention of agriculturists and extensive research is being carried out globally to enhance agrosustainability using such microbes.

\section{Biofertilizers: The Plausible Alternative}

Biofertilizers, a subclass of AIMs, are the naturally occurring biologically safe microorganisms, used for enhancing plant growth and enabling control and regulation of pests. Taking into concern the impressive role of biopesticides and biofertilizers in the promotion of sustainable agriculture, which basically include, target-specificity, environmental safety, and biodegradability [4-6], several government agencies are actively funding research and enhancing development and marketing of these green inputs In spite of the above notable mentions, it is extremely crucial to note that Asian countries consume only $5 \%$ of the total biopesticides sold globally while the North American Free Trade Agreement (NAFTA) countries claim to be the major global consumers of biopesticides $[7,8]$. Significantly, USA, Mexico and Canada consume about $47 \%$ of the biopesticides sold globally.

Microbes, particularly bacteria, have an inherent capability of plant growth promotion (PGP) and bioremediation. Bacterial genera, in particular, have been used as plant 
growth promoting agents since 1970s with a variety of reports justifying their capability of phosphate solubilization, nitrogen fixation, biological control of plant diseases and other PGP attributes. The current shift in agricultural practices has thereby gradually incorporated minimal use of agrochemicals in field practices while simultaneously employing bacterial microbiota as bio-inoculant, either singly or in consortia. Extensive research is being pursued in context of enhancing plant growth, yield and simultaneously conferring tolerance to unfavorable environmental or soil conditions by inoculating plants with PGPBs. The microbes are amalgamated with plant roots, shoots, leaves, as well as fruits or seeds thereby inducing a symbiotic relationship between plants and microorganisms. Earlier studies, mainly focused on the usage of PGPBs via rhizosphere application but continual explorations in this field, reported that these microbes can also be used through foliar application/sprays and inoculation via wounds (endophytic application), thereby enabling the retrieval of farmlands not formerly cultivable for fodder and feed.

\section{Endophytes: The Fundamental Branch of Bio- Fertilizers}

Endophytes are primarily soil-borne bacteria completing a major part of their life cycle within plants without causing any apparent symptoms [9]. The term "endophytes" is mainly used for those microorganisms which reside in vascular tissues of plant and move freely inside the plant, or it can be used more broadly to refer to any microorganism which resides inside the plant regardless of the tissue colonized.

Endophytes have particularly garnered the attention of sustainable agriculture as an alternative to rhizospheric PGPBs, particularly since; benefits conferred by endophytes acquire a competitive advantage over plant growth promoting rhizobia (PGPR) [10]. For instance, the survivability and colonizability of PGPR largely depend upon their intrinsic physiological properties as well as the biotic and abiotic factors of soil, whereas such is not the case with endophytes. Being in an intimate contact with the hosts, the endophytes remain largely protected from the abiotic and biotic stress conditions in the soil $[11,12]$. Another conspicuous feature of marked prominence is that re-introduction of endophytic bacteria does not affect the indigenous bacterial populations within host plants, unlike the introduction of PGPR in soil which causes an exemplar shift in the soil microbial community [13].

\section{Nutritional Benefits by Endophytic Bacteria}

Endophytic microbes endow hosts with a diversity of beneficial attributes, such as plant growth promotion, enhanced plant mineral uptake and yield [14-16], and as well as reduction of oxidative stress responses [17-21]. Thus it may be predicted that endophytes establish a dual fitness trait with the host wherein both the partners get synergistically benefitted [22]. In addition, endophytic microbes are also reported to cause an enhancement in water retention, and increment in biomass attained by a delay in flowering and leaf senescence, which further fix a greater amount of carbon within the host [23].

Endophytic microbes play a significant role in enhancing plant growth and yield. Endophytic production of plant auxin, indole acetic acid (IAA) from tryptophan is reported to occur via three alternative pathways:

a) Indolepyruvate and indole-3-acetaldehyde.

b) Tryptamine and indole-3-acetaldehyde and

c) Indole-3-acetamide and indole-3-acetonitrile [9].

The IAA so produced plays a significant rolein induction of 1-aminocyclopropane-1-carboxylate (ACC) synthaseand 1-aminocyclopropane-1-carboxylate (ACC) oxidase multigene family in hosts. Taghavi et al. [24] reported the presence of all the three pathways in endophyte Pseudomonasputida W619. Apart from the growth hormones, endophytic population is also reported tosecrete organic acids for solubilization of insoluble phosphates into soluble form followed by its uptake which is one of the pivotal elements involved in energy transfer, photosynthesis, carbohydrate transformation and transfer of hereditary characteristics [25]. Similarly, potassium and sodium ion content is also reported to be elevated within hosts. While, potassium ions play a pivotal role in enzyme activation, protein synthesis, cell metabolism and photosynthesis, sodium ionsare required in trace amounts in plants and primarily act as a vacuolar osmoticum [26]. In addition to the above perspectives, endophytic bacteria restrict the growth and development of phyto pathogens by releasing side rophores having strong affinity towards Fe (III) [27]. Post release, the microbes have certain Ton-B dependent membrane receptors for specific uptake of ferric-siderophore complexes or other small molecules [28].

Apart from aforementioned mechanisms, production of volatile substances such as 2-3 butanediol and aceotin seem to be a newly discovered mechanism responsible for plant growth promotion [29]. Acetolate synthase (AlsS) and acetolactate decarboxylase (AlsD) catalyze the switch from pyruvate to acetoin which further gets converted to 2, 3-butanediol either by the host or the endophyte. AlsDSacetoin synthesis pathway has been reported in endophytic Serratia proteamaculans 568 and Enterobacter 638 [24]. In yet another report, endophytes are recognized as producers of adenine nucleotides augmenting growth as well as diminishing browning of pine tissues [30].

\section{Remediation of Oxidative Stress}

A plethora of reports suggest endophytic microbes as having the capacity to control phytopathogens [31,32]. Several antagonistic endophytic bacterial species have been isolated from the xylem of lemon root, against root pathogens [33]. Endophytes enhance biocontrol activities in planta either directly by antibiosis or niche occupation [34] or indirectly 
by stimulating plant defense mechanisms [35]. Potentiality of endophytes as biocontrol agents are dependent on many factors, such as: host specificity, population dynamics and pattern of host colonization, ability to move within host tissues, and the ability to induce systemic resistance. It is believed that certain endophytic bacteria trigger induced systemic resistance (ISR), which is phenotypically similar to systemic acquired resistance (SAR). ISR is effective against different types of pathogens but differ from SAR in that the inducing bacterium does not cause visible symptoms on the host plant [36] (Figure 1).

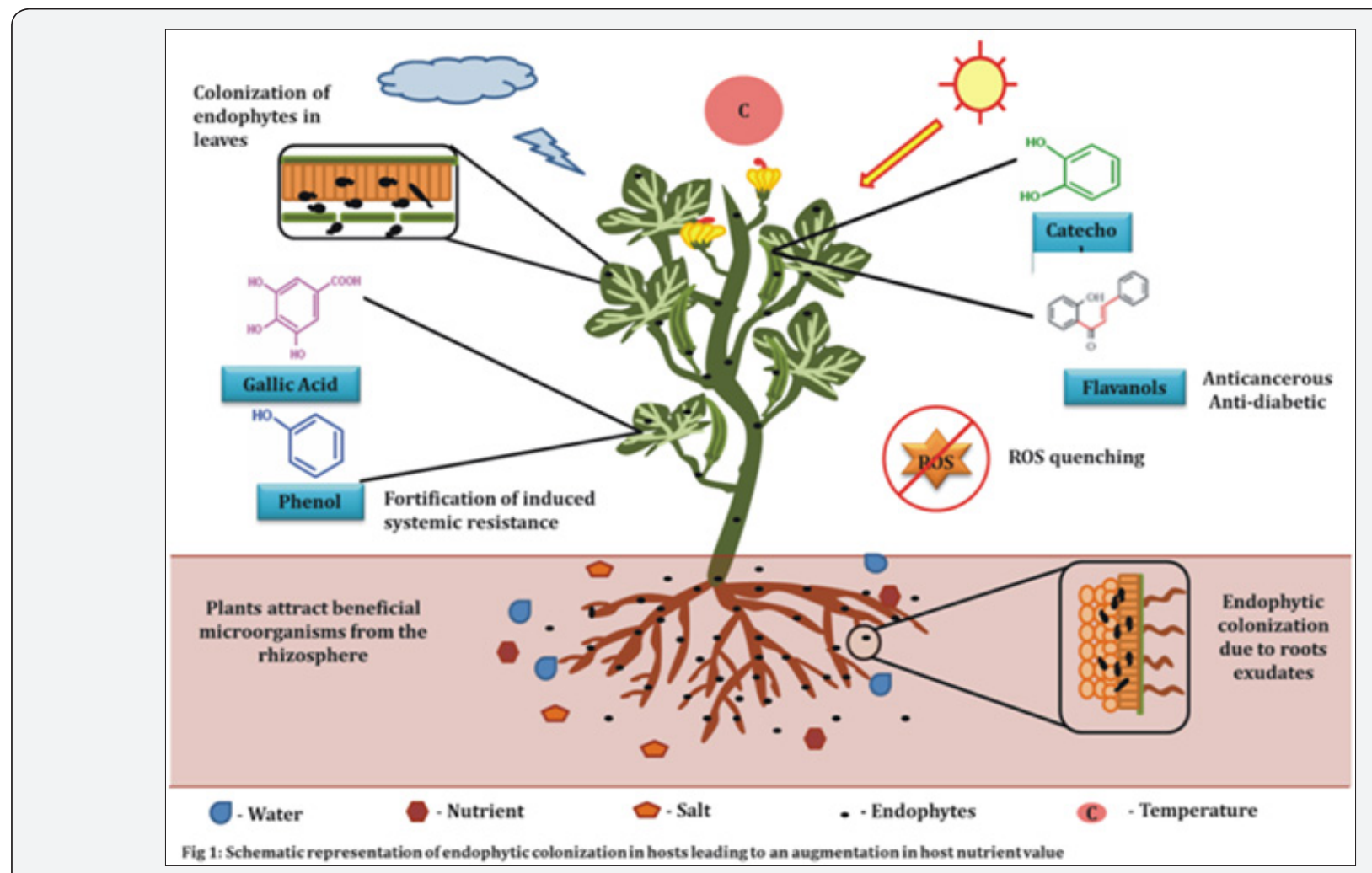

Figure 1: Schematic representation of endophytic colonization in leading to an augmentation in host nutrient value.

Hardoim et al. [37] suggested endophytes as reservoirs of enzymes possessing detoxification capacities, such as glutathione peroxidase (btuE), glutathione S-transferase (gst), catalase (katE), and nitric oxide reductase (nor). These enzymes probably function as mitigators of host oxidative burst process in response to endophytic colonization. Post colonization, these enzymes are responsible for fortification of the host to deal with any form of sudden stresses. In this context, Ray et al. [38] reported the augmentation of phenylpropanoid pathway have reported the augmentation of phenylpropanoid pathway thereby leading to a simultaneous increase in peroxidase and polyphenol oxidase enzymes against biotic stress.

\section{Endophytes as Generators of Antioxidants}

Due to challenge by any form of biotic or abiotic stress, an immediate release of reactive oxygen species (ROS), such as hydroxyl radical, hydrogen peroxide (H202), and superoxide anion (02-) occurs so as to mitigate the challenge $[39,40]$. However, these ROS are extremely catastrophic to the host tissues as these cause damage to cell membrane integrity as well as damage the cellular molecules, such as nucleic acids, proteins, etc. [41]. In order to diminish the disastrous effects of the ROS, plants generate antioxidants to quench the ROS and reactive nitrogen species so formed. Reports suggest that plants with an augmented antioxidant status are more beneficial to humans, particularly from the perspective of cure of chronic diseases, such as diabetes, cancer etc. [42,43].

In terms of antioxidant status, endophyte inoculated plants expressed an elevated level of antioxidant production particularly when exposed to abiotic or biotic stress [44]. An augmented antioxidant activity can be directly correlated to an increase in host biomass and root length $[38,45]$. In another report, Matsouri et al. [46] suggested endophyte inoculated hosts expressed an alteration in ratio of reduced and oxidized forms of glutathione and ascorbate. Similarly, Bae et al. [47] reported augmentation in levels of certain amino acids, for instance proline, which performed as osmoprotectants particularly when subjected to drought stress.

\section{Conclusion}

Irrespective of the significant contributions, study on endophytic bacteria, particularly with respect to 
enhancement in nutritional value of plants has still remained a realm quite unexplored. Though, having completed 71 years of independence, India still faces major challenges as far as agricultural development is concerned. Since India is primarily an agriculture based country, thus it is high time to exploit alternative modes of farming to yield improvement as well as nutritional benefit. This review is a minor attempt to appreciate the endophyte benefit bestowed upon hosts in terms of nutrient augmentation which is particularly significant with respect to sustainable agriculture as well as human health.

\section{Acknowledgement}

JS is grateful Council of Science and Technology, New Delhi, for providing assistance in form of junior research fellowship. RSR is grateful to Banaras Hindu University for providing financial assistance in form of UGC-RET fellowship.

\section{References}

1. Mishra S, Singh A, Keswani C, Saxena A, Sarma BK, et al. (2015) Harnessing plant-microbe interactions for enhanced protection against phytopathogens. In: Plant Microbes Symbiosis: Applied Facets Springer, India, pp. 111-125.

2. Bisen K, Keswani C, Mishra S, Saxena A, Rakshit A, et al. (2015) Unrealized potential of seed biopriming for versatile agriculture. InNutrient Use Efficiency: from Basics to Advances, Springer India, pp. 193-206.

3. Keswani C, Mishra S, Sarma BK, Singh SP, Singh HB (2014) Unraveling the efficient applications of secondary metabolites of various Trichoderma spp. Appl Microbiol Biotechnol 98(2): 533-544.

4. Kumar S, Singh A (2015) Biopesticides: present status and the future prospects. J Biofertil Biopestici 6: e129.

5. Keswani C, Singh SP, Singh HB (2013) A superstar in biocontrol enterprise: Trichoderma spp. Biotech Today 3(2): 27-30

6. Bisen K, Keswani C, Patel JS, Sarma BK, Singh HB (2016) Trichoderma spp.: efficient inducers of systemic resistance in plants. In: Microbialmediated Induced Systemic Resistance in Plants. Springer, Singapore, pp. 185-195.

7. Marrone PG (2007) Barriers to adoption of biological control agents and biological pesticides, $\mathrm{CAB}$ reviews: perspectives in agriculture, veterinary science, nutrition and natural resources. $\mathrm{CAB}$ International, Wallingford, UK, USA, 2(51).

8. Bailey KL, Boyetchko SM, Längle T (2010) Social and economic drivers shaping the future of biological control: a Canadian perspective on the factors affecting the development and use of microbial biopesticides. Biological Control 52(3): 221-229.

9. Hardoim PR, van Overbeek LS, van Elsas JD (2008) Properties of bacterial endophytes and their proposed role in plant growth.Trends Microbiol 16(10): 463-471.

10. Etesami H, Mirsyed Hosseini H, Alikhani HA (2014) In planta selection of plant growth promoting endophytic bacteria for rice (Oryza sativa L.). J Soil Sci Plant Nutr 14(2): 491-503.

11. Hallmann J, Quadt-Hallmann A, Mahaffee WF, Kloepper JW (1997) Bacterial endophytes in agricultural crops. Canadian Journal of Microbiology 43(10): 895-914.

12. Rajkumar M, Ae N, Freitas H (2009) Endophytic bacteria and their potential to enhance heavy metal phytoextraction. Chemosphere 77(2):153-160
13. Conn VM, Franco CM (2004) Analysis of the endophyticactino bacterial population in the roots of wheat (Triticumaestivum L.) by terminal restriction fragment length polymorphism and sequencing of $16 \mathrm{~S}$ rRNA clones. Appl Environ Microbiol 70(3): 1787-1794.

14. Malinowski DP, Belesky DP (2004) Adaptations of endophyte-infected cool-season grasses to environmental stresses: mechanisms of drought and mineral stress tolerance. Crop Science 40(4): 923-940.

15. Barka EA, Gognies S, Nowak J, Audran JC, Belarbi A (2002) Inhibitory effect of endophyte bacteria on Botrytis cinerea and its influence to promote the grapevine growth. Biological Control 24(2): 135-142.

16. Kang SH, Cho H, Cheong H, Ryu CM, Kim JF, et al. (2007) Two bacterial entophytes eliciting both plant growth promotion and plant defense on pepper (Capsicum annuum L.). J Microbiol Biotechnol 17(1): 96-103.

17. Bargabus RL, Zidack NK, Sherwood JE, Jacobsen BJ (2002) Characterisation of systemic resistance in sugar beet elicited by a non-pathogenic, phyllosphere-colonizing Bacillus mycoides, biological control agent. Physiological and molecular plant pathology 61(5): 289298.

18. Coombs JT, Michelsen PP, Franco CM (2004) Evaluation of endophytic actinobacteria as antagonists of Gaeumannomyces graminis var. tritici in wheat. Biological Control 29(3): 359-366.

19. Senthilkumar M, Govindasamy V, Annapurna K (2007) Role of antibiosis in suppression of charcoal rot disease by soybean endophyte Paenibacillus sp. HKA-15. Curr Microbiol 55(1): 25-29.

20. Bakker PA, Pieterse CM, Van Loon LC (2007) Induced systemic resistance by fluorescent Pseudomonas spp. Phytopathology. 97(2):239-43

21. Mishra A, Gond SK, Kumar A, Sharma VK, Verma SK, et al. (2012) Season and tissue type affect fungal endophyte communities of the Indian medicinal plant Tinospora cordifolia more strongly than geographic location. Microbial ecology 64(2): 388-398.

22. Sturz AV, Nowak J (2000) Endophytic communities of rhizobacteria and the strategies required to create yield enhancing associations with crops. Applied soil ecology 15(2): 183-190.

23. Owen NL, Hundley N (2004) Endophytes-the chemical synthesizers inside plants. Sci Prog 87 (pt 2): 79-99.

24. Taghavi S, Garafola C, Monchy S, Newman L, Hoffman A, et al. (2009 ) Genome survey and characterization of endophytic bacteria exhibiting a beneficial effect on growth and development of poplar trees. Applied and Environmental Microbiology 75(3): 748-757.

25. Taurian T, Anzuay MS, Angelini JG, Tonelli ML, Ludueña L, et al. (2010) Phosphate-solubilizing peanut associated bacteria: screening for plant growth-promoting activities. Plant and Soil 329(1-2): 421-431.

26. Shabala S, Cuin TA (2008) Potassium transport and plant salt tolerance. Physiologia Plantarum 133(4): 651-669.

27. Berg G, Krechel A, Ditz M, Sikora RA, Ulrich A, et al. (2005) Endophytic and ectophytic potato-associated bacterial communities differ in structure and antagonistic function against plant pathogenic fungi. FEMS Microbiol Ecol 51(2): 215-229.

28. Hurek BR, Hurek T (2011) living inside plants: bacterial endophytes. Curr Opin Plant Biol 4(4): 435-443.

29. Ryu CM, Farag MA, Hu CH, Reddy MS, Wei HX, et al. (2003) Bacterial volatiles promote growth in Arabidopsis. Proc Natl Acad Sci U S A 100(8): 4927-4932.

30. Pirttilä AM, Joensuu P, Pospiech H, Jalonen J, Hohtola A (2004) Bud endophytes of Scots pine produce adenine derivatives and other compounds that affect morphology and mitigate browning of callus cultures. Physiol Plant 121(2): 305-312. 
31. Sturz AV, Christie BR, Matheson BG, Nowak J (1997) Biodiversity of endophytic bacteria which colonize red clover nodules, roots, stems and foliage and their influence on host growth. Biology and Fertility of Soils 25(1): 13-19.

32. Krishnamurthy K, Gnanamanickam SS (1997) Biological control of sheath blight of rice: Induction of systemic resistance in rice by plantassociated Pseudomonas spp. Current Science 72(5): 331-334.

33. Araújo WL, Marcon J, Maccheroni W, van Elsas JD, van Vuurde JW, et al. (2002) Diversity of endophytic bacterial populations and their interaction with Xylella fastidiosa in citrus plants. Appl Environ Microbiol 68(10): 4906-4914.

34. Sturz AV, Christie BR, Nowak J (2000) Bacterial endophytes: potential role in developing sustainable systems of crop production. Critical reviews in plant sciences 19(1): 1-30.

35. Benhamou N, Kloepper JW, Tuzun S (1998) Induction of resistance against Fusarium wilt of tomato by combination of chitosan with an endophytic bacterial strain: ultrastructure and cytochemistry of the host response. Planta 204(2): 153-168.

36. Van Loon LC, Bakker PA, Pieterse CM (1998) Systemic resistance induced by rhizosphere bacteria. Annu Rev Phytopathol 36(1):453-83.

37. Hardoim PR, Van Overbeek LS, Berg G, Pirttilä AM, Compant S, et al. (2015) The hidden world within plants: ecological and evolutionary considerations for defining functioning of microbial endophytes. Microbiology and Molecular Biology Reviews 79(3): 293-320.

38. Ray S, Singh V, Singh S, Sarma BK, Singh HB (2016) Biochemical and histochemical analyses revealing endophytic Alcaligenes faecalis mediated suppression of oxidative stress in Abelmoschus esculentus challenged with Sclerotium rolfsii. Plant Physiol Biochem 109(1): 430 441.

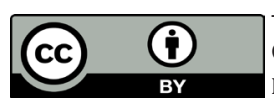

This work is licensed under Creative

Commons Attribution 4.0 License

DOI: $10.19080 /$ NFSIJ.2018.05.555657
39. Apel K, Hirt H (2004) Reactive oxygen species: metabolism, oxidative stress, and signal transduction. Annu Rev Plant Biol 55: 373-399.

40. White JF, Torres MS (2010) Is plant endophyte-mediated defensive mutualism the result of oxidative stress protection?. Physiol Plant 138(4): 440-446.

41. Halliwell B, Gutteridge JM (1999) Oxidative stress and antioxidant protection: some special cases. Free radicals in biology and medicine, pp. 485-543.

42. Podsedek A (2007) Natural antioxidants and antioxidant capacity of Brassica vegetables: A review. Food Science and Technology 40: 1-11.

43. Temple NJ (2000) Antioxidants and disease: more questions than answers. Nutrition research 20(3): 449-459.

44. Baltruschat H, Fodor J, Harrach BD, Niemczyk E, Barna B, et al. (2008) Salt tolerance of barley induced by the root endophyte Piriformospora indica is associated with a strong increase in antioxidants. New Phytol 180(2): 501-510.

45. Kumar M, Yadav V, Tuteja N, Johri AK (2009) Antioxidant enzyme activities in maize plants colonized with Piriformospora indica. Microbiology 155(pt3): 780-790.

46. Matsouri F, Björkman T, Harman GE (2010) Seed treatment with Trichoderma harzianum alleviates biotic, abiotic, and physiological stresses in germinating seeds and seedlings. Phytopathology 100(11): 1213-1221.

47. Bae H, Sicher RC, Moon SK, Kim SH, Strem MD, et al. (2009) The beneficial endophyte Trichoderma hamatum isolate DIS $219 \mathrm{~b}$ promotes growth and delays the onset of the drought response in Theobroma cacao. Exp Bot 60(11): 3279-2395.

\section{Your next submission with Juniper Publishers will reach you the below assets}

- Quality Editorial service

- Swift Peer Review

- Reprints availability

- E-prints Service

- Manuscript Podcast for convenient understanding

- Global attainment for your research

- Manuscript accessibility in different formats

( Pdf, E-pub, Full Text, Audio)

- Unceasing customer service

Track the below URL for one-step submission https://juniperpublishers.com/online-submission.php 